Article

\title{
An Integrated Approach for Site Selection of Snow Measurement Stations
}

\author{
Bahram Saghafian ${ }^{1, *}$, Rahman Davtalab ${ }^{2}$, Arezoo Rafieeinasab ${ }^{3}$ and M. Reza Ghanbarpour ${ }^{4}$ \\ 1 Technical and Engineering Department, Science and Research Branch, Islamic Azad University, \\ Tehran 1477893855, Iran \\ 2 Department of Civil, Environmental and Construction Engineering, University of Central Florida, \\ Orlando, FL 32818, USA; rdavtalab@saiengineers.com \\ 3 Department of Civil Engineering, The University of Texas at Arlington, Box 19308, 416 Yates St. Suite 425, \\ Arlington, TX 76019, USA; arezoo.rafieeinasab@gmail.com \\ 4 Alberta Environment and Parks, Calgary, AB T2E 7L7, Canada; Reza.Ghanbarpour@gov.ab.ca \\ * Correspondence: b.saghafian@gmail.com; Tel.: +98-912-327-7808
}

Academic Editor: Tommaso Moramarco

Received: 28 June 2016; Accepted: 7 November 2016; Published: 17 November 2016

\begin{abstract}
Snowmelt provides a reliable water resource for meeting domestic, agricultural, industrial and hydropower demands. Consequently, estimating the available snow water equivalent is essential for water resource management of snowy regions. Due to the spatiotemporal variability of the snowfall pattern in mountainous areas and difficult access to high altitudes areas, snow measurement is one of the most challenging hydro-meteorological data collection efforts. Development of an optimum snow measurement network is a complex task that requires integration of meteorological, hydrological, physiographical and economic studies. In this study, site selection of snow measurement stations is carried out through an integrated process using observed snow course data and analysis of historical snow cover images from National Oceanic Atmospheric Administration Advanced Very High Resolution Radiometer (NOAA-AVHRR) at both regional and local scales. Several important meteorological and hydrological factors, such as monthly and annual rainfall distribution, spatial distribution of average frequency of snow observation (FSO) for two periods of snow falling and melting season, as well as priority contribution of sub-basins to annual snowmelt runoff are considered for selecting optimum station network. The FSO maps representing accumulation of snowfall during falling months and snowpack persistence during melting months are prepared in the GIS based on NOAA-AVHRR historical snow cover images. Basins are partitioned into $250 \mathrm{~m}$ elevation intervals such that within each interval, establishment of new stations or relocation/removing of the existing stations were proposed. The decision is made on the basis of the combination of meteorological, hydrological and satellite information. Economic aspects and road access constraints are also considered in determining the station type. Eventually, for the study area encompassing a number of large basins in southwest of Iran, several new stations and relocation of some existing stations are proposed.
\end{abstract}

Keywords: snow measurement network; site selection; satellite images; Iran

\section{Introduction}

Water demand increase in urban, agriculture and industry sectors all over the world continues to intensify the pressure on water resources. In the southwestern of Iran, the Karkheh, Dez, Karun and Marun river basins provide over a quarter of surface water resources in the country and even supply water for the central arid part of Iran via transboundary water transfers [1].

Nowadays, hydrological and water resources modeling play a key role in water resources management [2]. On the other hand, development and calibration of hydrologic and water resources 
models rely on adequate and accurate hydro-climatic observation data [3]. Reliable data may be acquired through appropriate design, installation and operation of an optimum network of hydro-climatic stations. Designing a proper measurement network results in the representative location and optimum number of stations so that interpolation techniques can lead to acceptable estimation of spatially distributed factors with adequate accuracy $[4,5]$.

Among the hydro-climatic variables, snow is one of the most important factors in the hydrology of mountainous areas. Snow, as a renewable water resource, remains on the ground for weeks or months. Since the lag time of river flow from snowmelt is more than that of rainfall, management of this reliable resource is relatively easier. The amount of snowfall and snowmelt depends on both geographic (elevation, slope and aspect, latitude, etc.) and synoptic factors. Storing and melting snow is a continuous process especially in southwest of Iran with low latitude and relatively ephemeral snow. Therefore estimating accumulated snowpack and its spatiotemporal pattern is complex. Furthermore, due to limited access to high altitudes of mountainous areas, snow measurement is considered as one of the most difficult data collections in water resources. The position of snow gauges and the type of snow measurement instruments should be selected in a way to represent the spatial and temporal variations of snow characteristics. Selecting representative locations for automated snow-pillow (ASP) stations or manual snow-course (MSC) stations will ensure access to the reliable data required for snow storage estimation.

Nowadays, satellite images and remote sensing (RS) techniques are widely used for the estimation of snow cover areas. Derived snow cover areas from satellite images accompanied with field observations can provide a unique tool for estimation of snow storage, river flow forecasting and flood control required in water resource management.

ASP measurement networks have been developed in many countries. The snow measurement network in western U.S. states or SNOTEL [6], provincial or local networks in Canada, such as ASP measurement network in British Columbia [7], and the ASP measurement network in Pakistan [8] are good examples of available operating networks.

Nonetheless, there are insufficient studies on site selection of snow measurement networks at regional scale and a few existing studies are limited to local scale, focusing mainly on a single station [6]. According to the World Meteorological Organization [9], the number of snow measurement stations or snow courses and their positions depend on topography, the type and aspect of vegetation, the objectives of data collection, and economic considerations. WMO recommended one snow measurement station for about 2000 to $3000 \mathrm{~km}^{2}$ in low homogeneous region and one for about 5000 $\mathrm{km}^{2}$ for more homogeneous and plain regions [9]. For developing a snow measurement network, it is recommended to establish a temporary and dense network that measures the snow parameters for four to six years continuously in order to detect snow cover characteristics, related to the physiographical parameters. Then, according to the required accuracy, operation constraints and cost minimization, the network density may be reduced [4].

In this study, areas will be prioritized according to the need for snow measurement stations using field observations that are supported by satellite snow cover images. Furthermore, through assessment of the existing snow measurement network in each of the altitudinal range, installation of new stations, removal/maintaining/relocation of the existing stations MSC stations, or upgrade to ASP stations is proposed. The paper is organized as follows. Case study, data acquisition, and methodology, including the meteorological, hydrological, and remote sensing criteria used are described in Section 2. Results are presented in Section 3. Section 4 provides conclusions and recommendations.

\section{Data and Methods}

\subsection{Study Area}

The Zagros Mountains are one of the major snowy regions of Iran, which include the four large river basins of Karkheh, Dez, Karun and Marun. The study area encompasses the Karkheh basin, 
upstream of Karkheh Dam, with approximately 43,000 km² in area and $5.2 \mathrm{~km}^{3}$ mean annual runoff; Dez Basin, upstream of Dez Dam with $17,300 \mathrm{~km}^{2}$ in area and $8.4 \mathrm{~km}^{3}$ mean annual runoff; Karun basin, upstream of Gotvand Dam with $32,000 \mathrm{~km}^{2}$ in area and $12.5 \mathrm{~km}^{3}$ mean annual runoff; and two tributaries of the Marun basin, first upstream of Shohadaye Behbahan Dam and second upstream of Jarreh Dam with $6800 \mathrm{~km}^{2}$ in area and $2.3 \mathrm{~km}^{3}$ mean annual runoff, in total. The area lies between the geographical latitude of $30^{\circ} 15^{\prime} \mathrm{N}$ to $34^{\circ} 55^{\prime} \mathrm{N}$ and $46^{\circ} 05^{\prime} \mathrm{E}$ to $52^{\circ} 03^{\prime} \mathrm{E}$ longitude. The mentioned river basins play a major role in food production and economy of more than 4 million people [10,11]. Figure 1 shows the location of these major river basins.

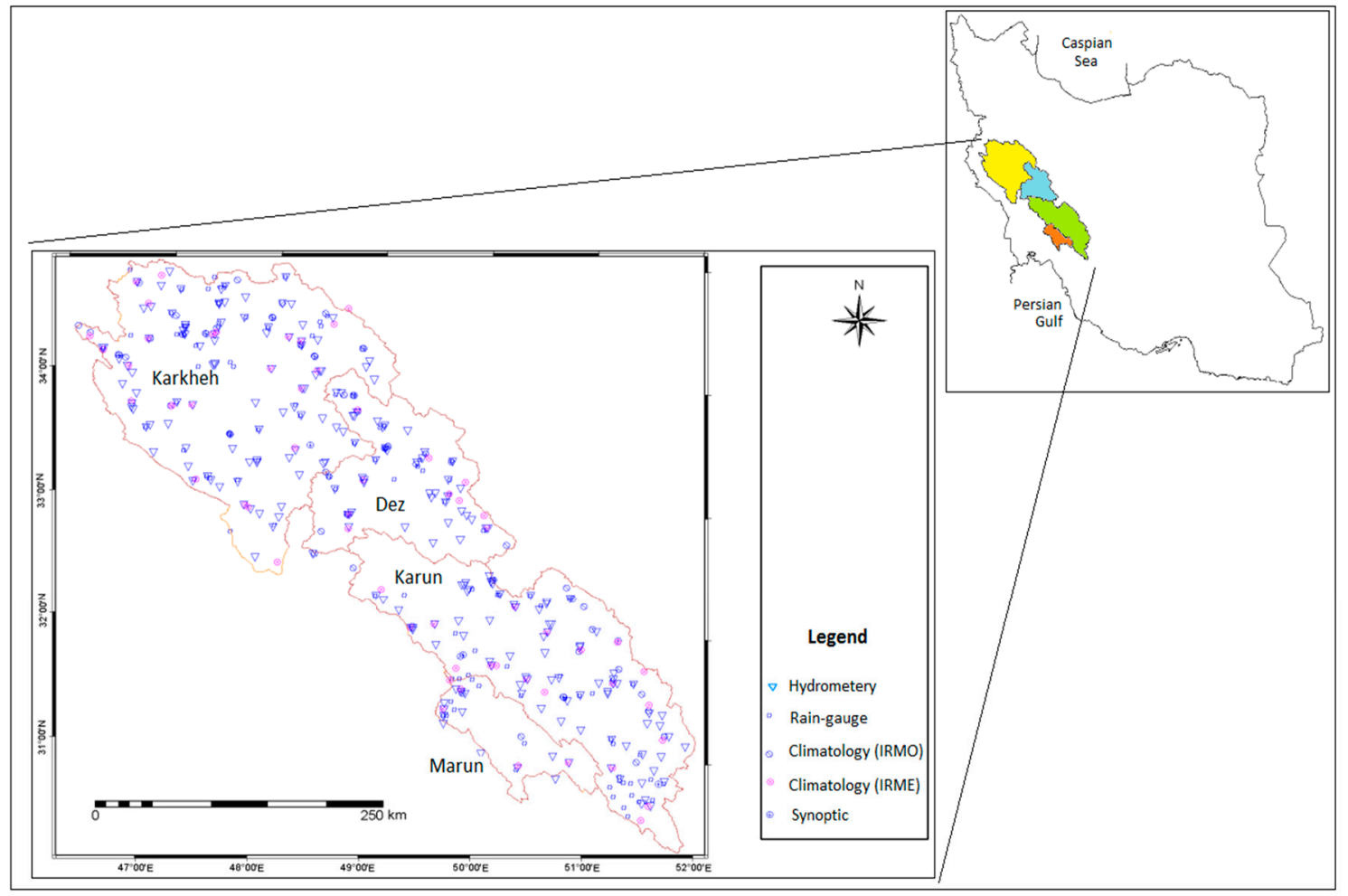

Figure 1. Location of the study basins and distribution of the meteorological and hydrometric stations.

\subsection{Data Collection}

The data used for this study comprise the monthly air temperature from 44 climatological stations (including the stations installed by Iran Ministry of Energy, IRME and Iran Meteorological Organization, IRMO), daily and monthly precipitation of 152 rain-gauge stations, daily temperature and 3-h precipitation depth and 6-h precipitation type (rainfall or snow) measured at 20 synoptic stations, snow water equivalent and snow depth at 45 available MSC stations accompanied by daily discharge at 40 hydrometric stations with long term data (Figure 1). For monthly temperature and rainfall, a 25-year data period is identified as a normal climate period (1974-1999). Missing data are reconstructed using linear correlation with the nearest neighboring station. The snow water equivalent may also be estimated through analysis of the amount and type of precipitation in the form of rainfall or snowfall, at synoptic stations (detail information is available in Saghafian and Davtalab, [12]). The only snow measurements available from MSC stations that are located in the Karun and Dez Basins. Data sampling in the mentioned stations is performed manually once a year. However, the sampling time varies between late February and late March. Therefore, the sampling period lasts about one month in any given year. Accordingly, the above-mentioned data are used for spatial analysis.

Quantity and quality of daily discharge data are assessed as well and the annual discharge series are obtained. The snow cover maps extracted from the National Oceanic Atmospheric Administration 
Advanced Very High Resolution Radiometer (NOAA-AVHRR) series for the period of 1984 to 2003 have been used in this study. The maps are provided by Jamab [13] based on the methodology available in Porhemmat et al. [14]. The spatial resolution of the NOAA-AVHRR image is about $1.1 \mathrm{~km}$, suitable for snow cover extraction over vast areas. There are two images for every $24 \mathrm{~h}$, one of which corresponds to daytime. However, not all daytime images were suitable because of atmosphere noise and/or cloud cover. In all, 480 snow cover maps were available in Jamab's archive [13]. The snow cover maps are stored in binary format in GIS (1 denotes snow and 0 denotes non-snow pixel). The hypsometric maps, boundary of basins and sub-basins, digital elevation model (DEM), slope and aspect maps are derived from 1:250,000 topographic maps (Iran National Cartographic Center: http:/ /www.ncc.org.ir) with $100 \mathrm{~m}$ contour interval. For instance, the contour map for Dez Basin is shown in Figure 2.

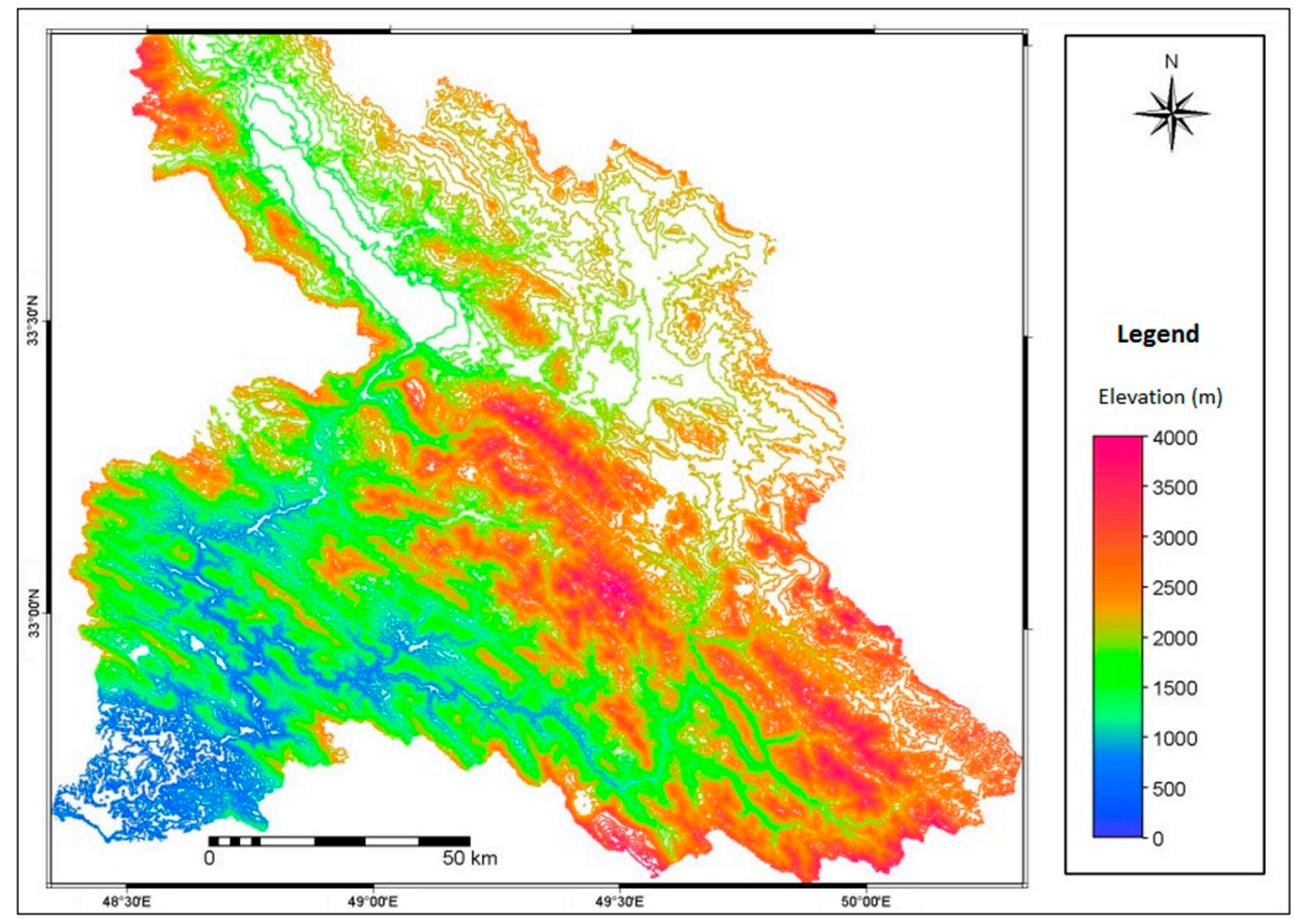

Figure 2. Elevation contour map of Dez Basin.

\subsection{Methodology}

The snow station site selection methodology is based on integration of meteorological, hydrological, and remote sensing studies. Meteorological analysis includes preparation of isothermal and isohyetal maps, determination of snowfall threshold temperature and precipitation estimation variance analysis [15]. Prioritization of the sub-basins has been done based on the contribution of snowmelt to the total annual runoff in each sub-basin. Analysis of remote sensing data includes the extraction of the FSO layers for two periods of snowfall accumulation and snowpack persistence. The details are given in the following sections of the paper.

\subsubsection{Meteorological Criteria}

Temperature is the most dominant meteorological factor in determination of precipitation type (snow and rain) and determines regions subject to snowmelt, snowfall, or both. Therefore, temperature and its spatial variation is a key factor in determining the proper location of snow measurement stations. In this study, the snowfall threshold temperature refers to the temperature under which the precipitation is assumed to be in the form of snow. Threshold temperature may vary from below $0{ }^{\circ} \mathrm{C}$ to $5{ }^{\circ} \mathrm{C}$ and may not be constant even in a single day [16]. Therefore, in many studies an average value 
is used as threshold temperature $[2,17,18]$. Daily precipitation data accompanied with the rain/snow observation at synoptic stations are used to estimate the threshold temperature [16].

In each station, through assigning the snowfall percentage in various temperature intervals, the temperature corresponding to $50 \%$ snowfall is determined as the threshold temperature. Based on the monthly and annual mean temperature for the study period at all stations, the spatial correlation relationships between temperature and elevation are found using DEMs. The areas below the threshold temperature are identified as potential snow storage areas using the isothermal maps. Hence, establishing snow gauges is considered in these areas.

In addition, the semi-variogram analysis [15] is conducted using observed snow water equivalent (SWE) data from snow measurement stations or MSC stations (average of SWE for the period of 1974 to 1999). The best variogram model is adopted to compute the spatial distribution of error variance. Estimation variance denoted by $\sigma_{e}^{2}$ demonstrates the variance of the error between observed and estimated values. In geostatistics, it can be computed from average values of semi-variograms using available supplementary functions [19]. In addition, for calculation of confidence levels, estimation variance is used in many other cases, such as designing an optimal measurement network, calculating the error reduction resulted from increasing the number of sampling, and assessing different sampling methods. Estimation variance can be defined with the following equation [20]:

$$
\sigma_{e}^{2}=2 \sum_{i=1}^{n} \lambda_{i} \times \gamma_{o i}-\gamma_{o}-\sum_{i=1}^{n} \sum_{j=1}^{n} \lambda_{i} \times \gamma_{i j}
$$

where $\lambda_{i}$ is weight of data at point $i, \gamma_{0}$ is the variogram value for $h=0$, (where $h$ is the distance between paired points), $\gamma_{o i}$ is the variogram value between the considered point and point $i, \gamma_{i j}$ is the variogram value among $i$ and $j$ samples and $\sigma_{e}^{2}$ is the estimation variance at the $i$ th point.

Further explanation about the error variance map is available in [19]. Error variance maps are used as the main reference in determining the new locations of a gauge or omitting redundant gauges. Therefore, snow measurement stations can be established where error variance is high. The reduction of spatial error variance corresponding to adding one station can also be determined.

\subsubsection{Hydrological Criteria}

In mountainous areas with a mixed snow-rain precipitation regime, the contribution of snowmelt to the annual runoff is an important factor. Because of the inherent uncertainty in the separation of flow components, a simple water balance model is used [21]. Precipitation over the melting season, annual runoff coefficient and snowmelt runoff determined for each hydrometric station are accounted in the water balance model, which can be expressed as follows:

$$
R=\left(H_{w}+P\right) \times C
$$

where $R$ is the total runoff over the snowmelt season in millimeters, $H_{w}$ is the depth of SWE at the beginning of the snowmelt season in millimeters, $P$ is the precipitation over the snowmelt season (spring and summer) in millimeters and $C$ is the average runoff coefficient that can be computed based on precipitation and discharge data. $P$ is calculated based on monthly isohyetal maps. $H_{w}$ represents the unknown of the model.

Having determined $R$ at hydrometric stations, a regional model is developed to estimate $R$ at ungauged locations. Basin characteristics such as area, average elevation, and the percentage of areas with elevation above 2000, 2500 and $3000 \mathrm{~m}$ are used as independent variables of the regional model [22]. As a result, a map of $R$ values at sub-basin scale is produced such that sub-basins may be prioritized based on snowmelt runoff contribution. This map is used as one of the criteria in selection of snow measurement stations. 


\subsubsection{Remote Sensing Snow Observation Criteria}

Time series of snow cover maps were available from Jamab [13]. These maps had been extracted from NOAA-AVHRR images for the period of 1984-2003. Detailed description of image geo-referencing, noise reduction, and snow cover extraction are available in Porhemmat et al. [14]. In brief, the methodology of snow detection by Porhemmat et al. [14] has two steps of split and merge technique on AVHRR satellite images, channels 2, 3 and 4. In the first step, two split-and-merge clustering/labeling procedures were used in order to separate clear land pixels from pixels contained by either snow or cloud as described by Simpson et al. [23]. In the second stage, the same procedure was used only on pixels containing cloud, snow or a mixture of both. At this stage, pixels containing snow were distinguished from those containing cloudy pixels. To improve and control this computerized procedure, the above methodology was combined with threshold techniques and filter analysis of AVHRR channels data, especially channel 2, 3, and 4. Due to the high contrast between snow covered and snow free surfaces, channel 1 facilitates the definition of snow pack boundaries. Also, channel 3 and channel 4 analyses were effectively used as the snow/cloud discrimination channels. Validation of the NOAA snow detection algorithm was performed against eye interpretation via on screen digitization of simultaneous NOAA and Landsat TM images.

The FSO derived from the mentioned snow cover maps is a key criterion for identifying the potential snowy areas. The following relationship for calculating FSO has been proposed by Saghafian and Davtalab [12]:

$$
F S O(i)=\frac{\sum_{l=1}^{T} X(i, l)}{T} \times 100
$$

where $F S O(i)$ is frequency of snow observations for the $i$-th pixel, $T$ is the total number of snow cover maps over the study period and $X$ is a binary number equal to one if it is snow and zero otherwise.

In this study FSO is calculated for two time periods of December-February and March-May. Since the study area receives snow from early December to late February [12], FSO during these months is considered as snowfall probability (FSO-SFP). Also, almost all snow storage of study area melts during March until end of May. Therefore, FSO during these months is considered as snowpack persistence probability (FSO-SPP). FSO-SPP is dependent on temperature, additional precipitation and topographic conditions of the land $[24,25]$. Snow may disappear quickly due to temperature increase and/or shallow depth of snow. Snowmelt and loss of snow storage occurs faster along southern aspects because of direct sunshine [24,25]. Since spring and summer are high water demand seasons in the study area, FSO-SPP or snowpack persistence is important for meeting the water demands.

\subsubsection{Synthesis of Criteria in Site Selection}

As previously mentioned, the study area is divided into $250 \mathrm{~m}$ elevation intervals. Establishment/relocation of new/existing snow measurement stations is analyzed within each interval. The area ratio of each elevation interval to the total basin area is considered as a weight index. The weighted average snowfall probability in each interval is also calculated, using FSO-SFP map. This criterion is used as one of the main factors in snow station site selection.

The areas with FSO-SFP higher than the weighted average snowfall probability are identified in each elevation interval that has no snow measurement station. If spatial distribution of the identified areas were like patchy snow cover, those small polygons were eliminated. Then the meteorological and hydrological criteria are taken into account so that the areas with no or minimal snowfall potential and/or sub-basins with low snowmelt runoff volume are eliminated in further analyses.

However, if a snow measurement station is already operational in an altitudinal range, the appropriateness of its present location is assessed based on the criteria such as FSO-SFP, FSO-SPP and field visit.

In addition, the spatial pattern of stations is investigated according to the estimation variance maps. Therefore, new stations are likely to be proposed in areas subject to high estimation variance. The FSO-SPP map is further used as a reference in very large areas of high variance to reduce the field visit 
area. Clearly, areas with FSO-SPP higher than the weighted average snowpack persistence probability are appropriate areas for establishing new stations, since they provide the snow storage data for simulating snowmelt runoff over dry seasons.

After determining suitable areas at regional or macro scale, topography, road access, and proximity with residential areas (to facilitate the operation and maintenance of stations) are the main factors for site selection of snow stations at local or micro scale. The final step for site selection was field study to determine the exact point for installing the stations based on WMO recommendations [26]. The following criteria has been considered during the field study for selecting the representative location for the snow course: leaving clear space within the radius of at least equal to the height of the nearest obstacle, absence of strong wind and snowdrift (as much as possible), safety of the station against avalanche, no significant changes in elevation in a radius of $50 \mathrm{~m}$ (if possible), no reverse slopes and hard surface conditions for ease of leveling, good drainage, homogeneous vegetation cover and land use in the vicinity, and having enough open space to avoid snow interception.

For sake of brevity, only Dez Basin results will be presented.

\section{Results}

\subsection{Classification of Regions Based on Meteorological Criteria}

Isothermal maps are developed using the digital elevation model (DEM) and the temperature gradient relationships. The average threshold temperature is $2.4^{\circ} \mathrm{C}$ at most synoptic stations, which is assigned as the threshold for the entire region (more explanation is available in Saghafian et al. [16]). The area with average monthly temperature less than $2.4{ }^{\circ} \mathrm{C}$ are designated as the potential snowfall areas and areas with temperature below $0{ }^{\circ} \mathrm{C}$ are classified as the potential area for snow persistence. Therefore, the regions with temperature between $0{ }^{\circ} \mathrm{C}$ and $2.4{ }^{\circ} \mathrm{C}$ represent areas prone to coupled snowfall-snowmelt processes. Figure 3 illustrates the spatial distribution of potential snowfall, snowmelt, and snow persistence areas in February in Dez Basin.

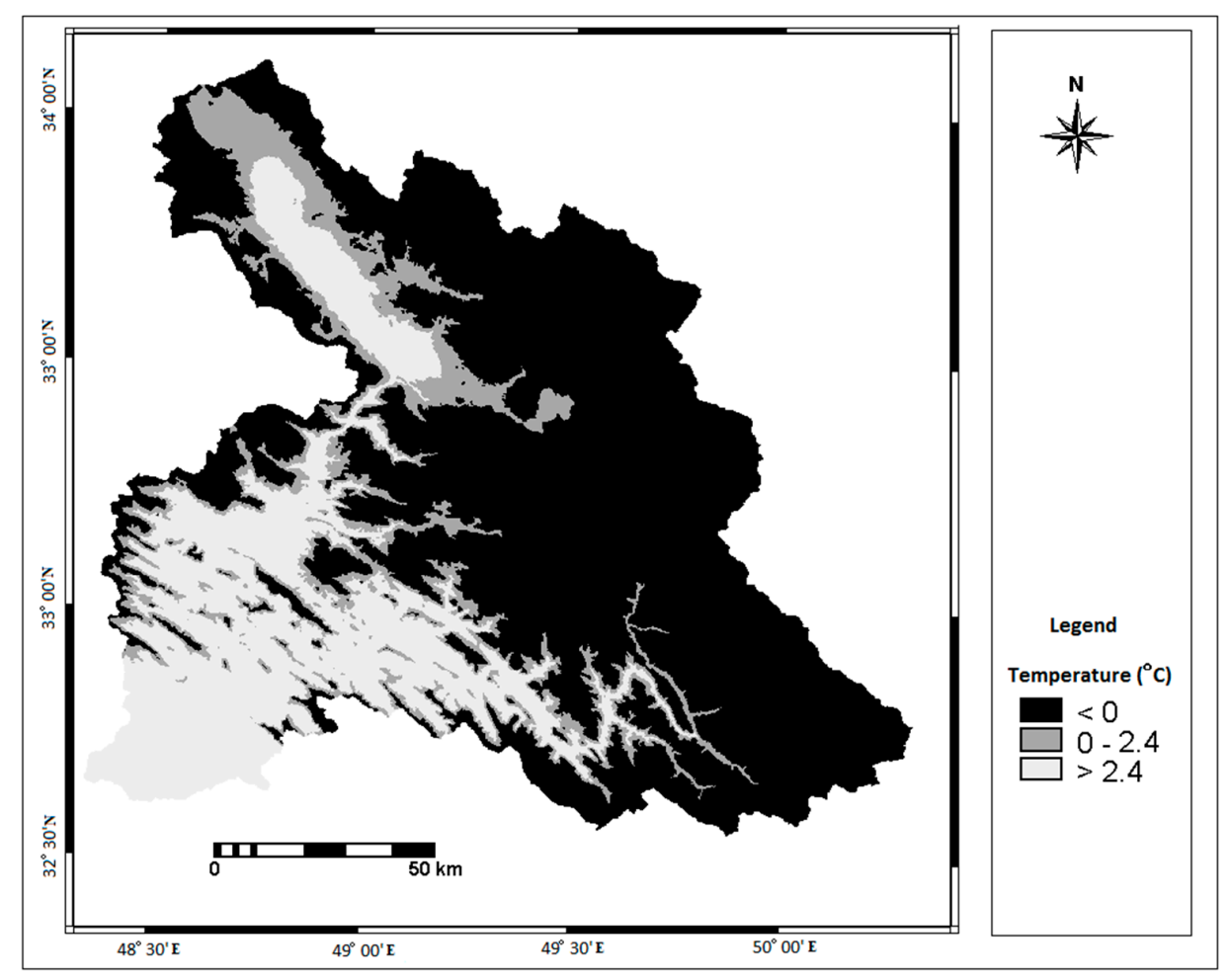

Figure 3. Potential areas for snow persistence $\left(T<0{ }^{\circ} \mathrm{C}\right)$, snowfall $\left(0<T<2.4{ }^{\circ} \mathrm{C}\right)$ and snowmelt $\left(T>2.4^{\circ} \mathrm{C}\right)$ in Dez Basin in February (for the period of 1974-1999). 
Semi variogram analysis is carried out using the average of SWE data over the historical period, and the spatial distribution of estimation error variance is extracted using the best variogram model. Since the SWE data are available only for Dez and Karun basins, the performed estimation error variance analyses are limited to these basins. Figure 4 shows the error variance in the Dez Basin, areas with higher error are candidates for establishment of new stations.

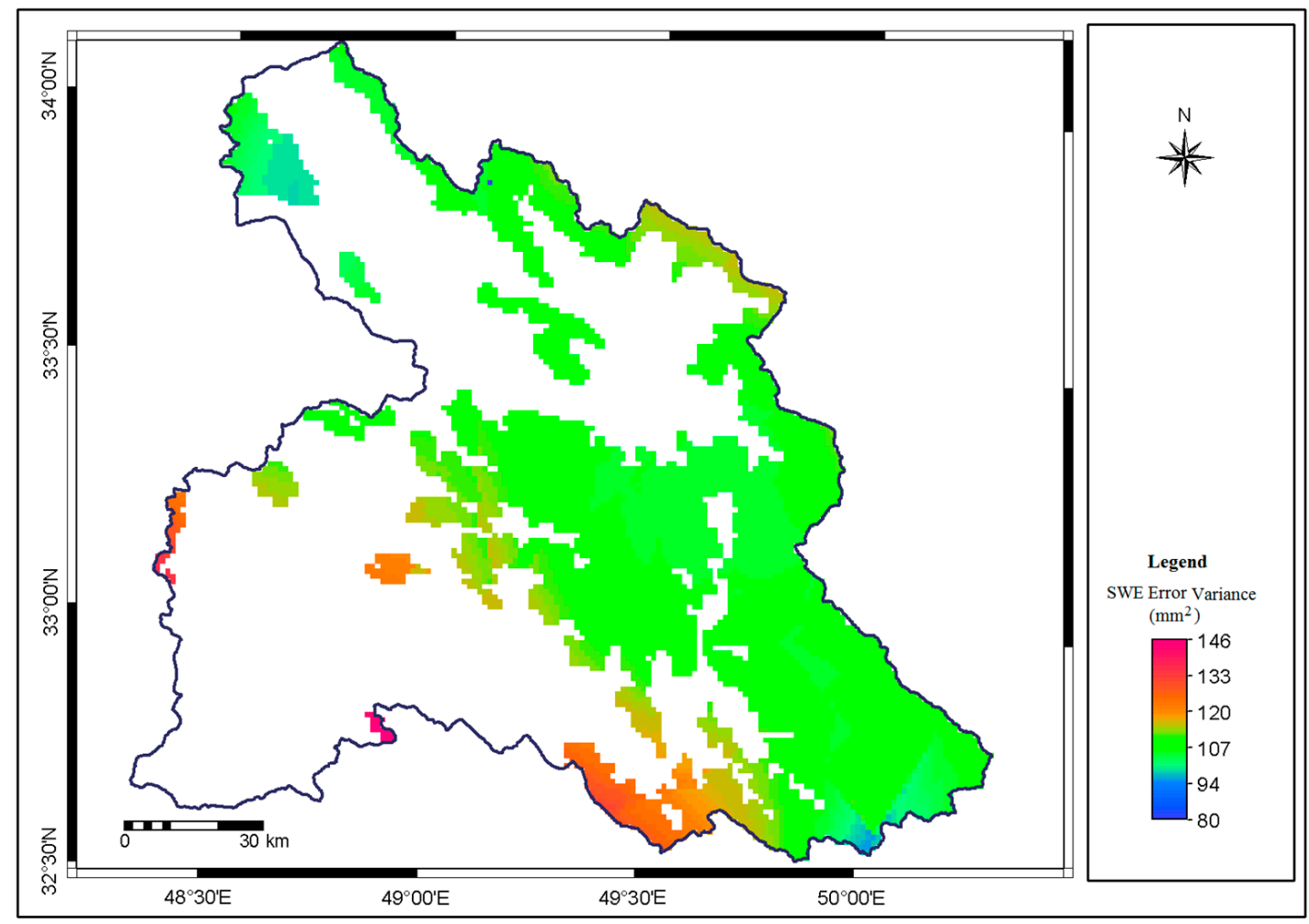

Figure 4. Error variance map of snow water equivalent for Dez Basin.

\subsection{Hydrological Criteria}

Snowmelt runoff volumes at 40 hydrometric stations are calculated based on the water balance model. Figure 5 shows the location of the selected stations in Dez Basin and all the hydrometric stations are shown in Figure 1. A regional regression model between snowmelt runoff volume and the percent of basin area higher than $2500 \mathrm{~m}$ is then built in order to provide estimates of snowmelt runoff at sub-basin outlets without hydrometric station (more information is available in Ghanbarpour et al. [22]). Snowmelt runoff volume and the corresponding priority in Dez Basin are given in Table 1 as an example.

Table 1. Snowmelt runoff volume and the corresponding priority in Dez Basin.

\begin{tabular}{ccc}
\hline Sub-Basin & Snowmelt Runoff $(\mathbf{m m})$ & Priority \\
\hline Upstream of Tang Sezar & 4.7 & 7 \\
Upstream of Sepidan & 12.4 & 6 \\
Upstream of Sezar & 44.7 & 2 \\
Upstream of Tang Bakhtiari & 42.5 & 3 \\
Upstream of Zard Fahreh & 84.2 & 1 \\
Upstream of Daretakht & 25.5 & 4 \\
Upstream of Doroud & 22.7 & 5 \\
\hline
\end{tabular}




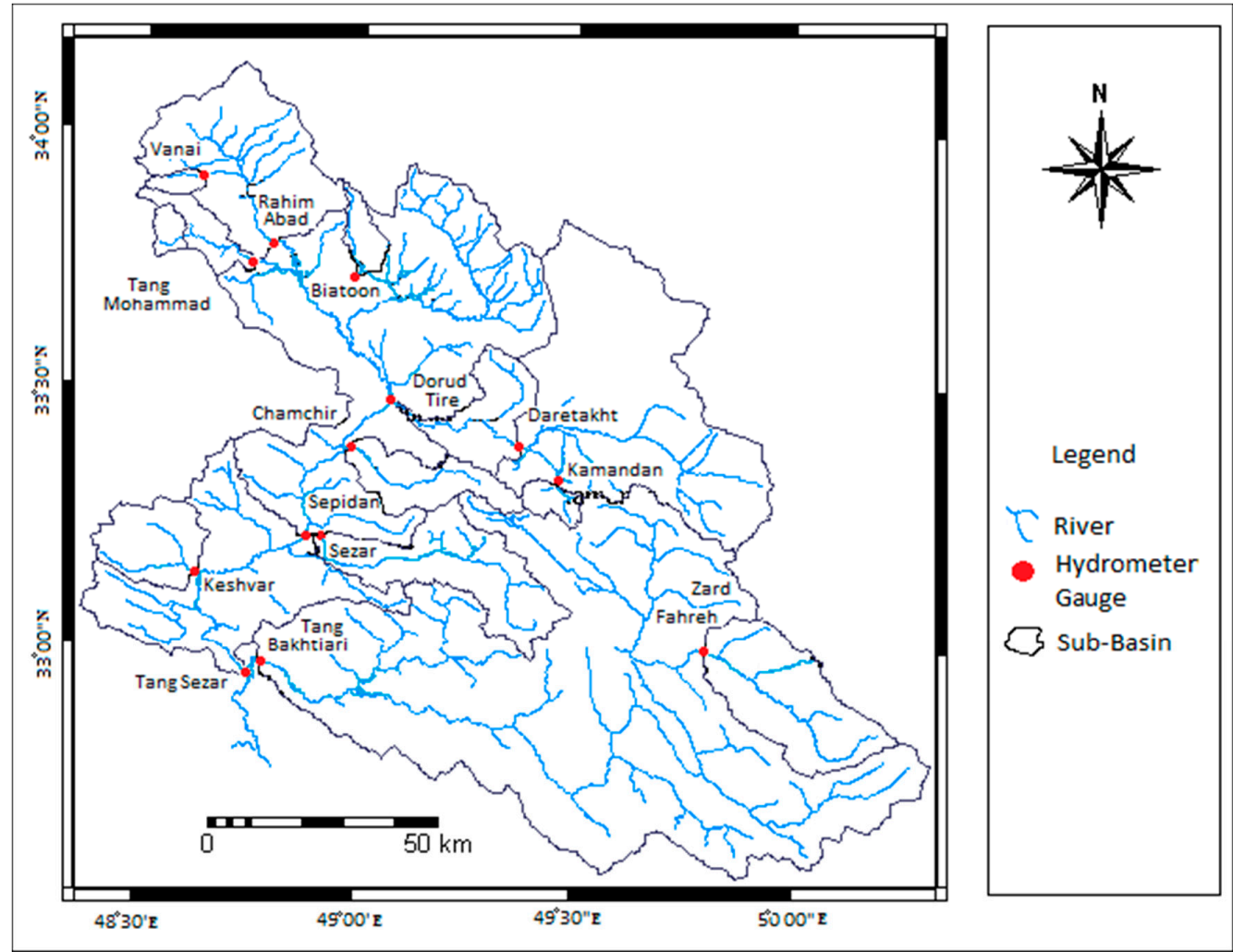

Figure 5. Selected hydrometric stations in Dez Basin.

\subsection{Snowfall and Snowpack Persistence Probability Criteria}

As previously indicated the FSO-SFP and FSO-SPP maps are derived based on Equation (3) over the snowfall and snowmelt seasons, respectively. These two layers represent the spatial distribution of the probability of the accumulation and persistence of snow that are key factors in site selection. Figures 6 and 7 show FSO-SFP and FSO-SPP maps in Dez Basin, respectively.

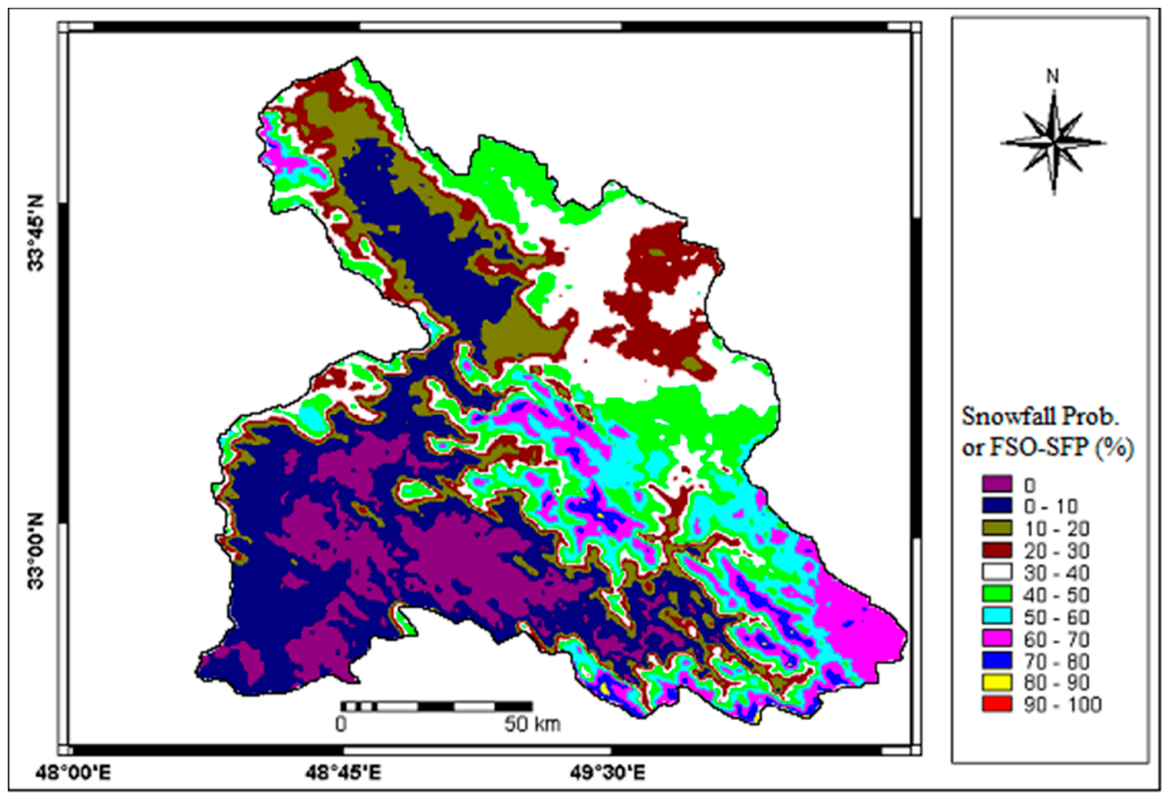

Figure 6. FSO-SFP Map in Dez Basin (for the period of 1984-2003). 


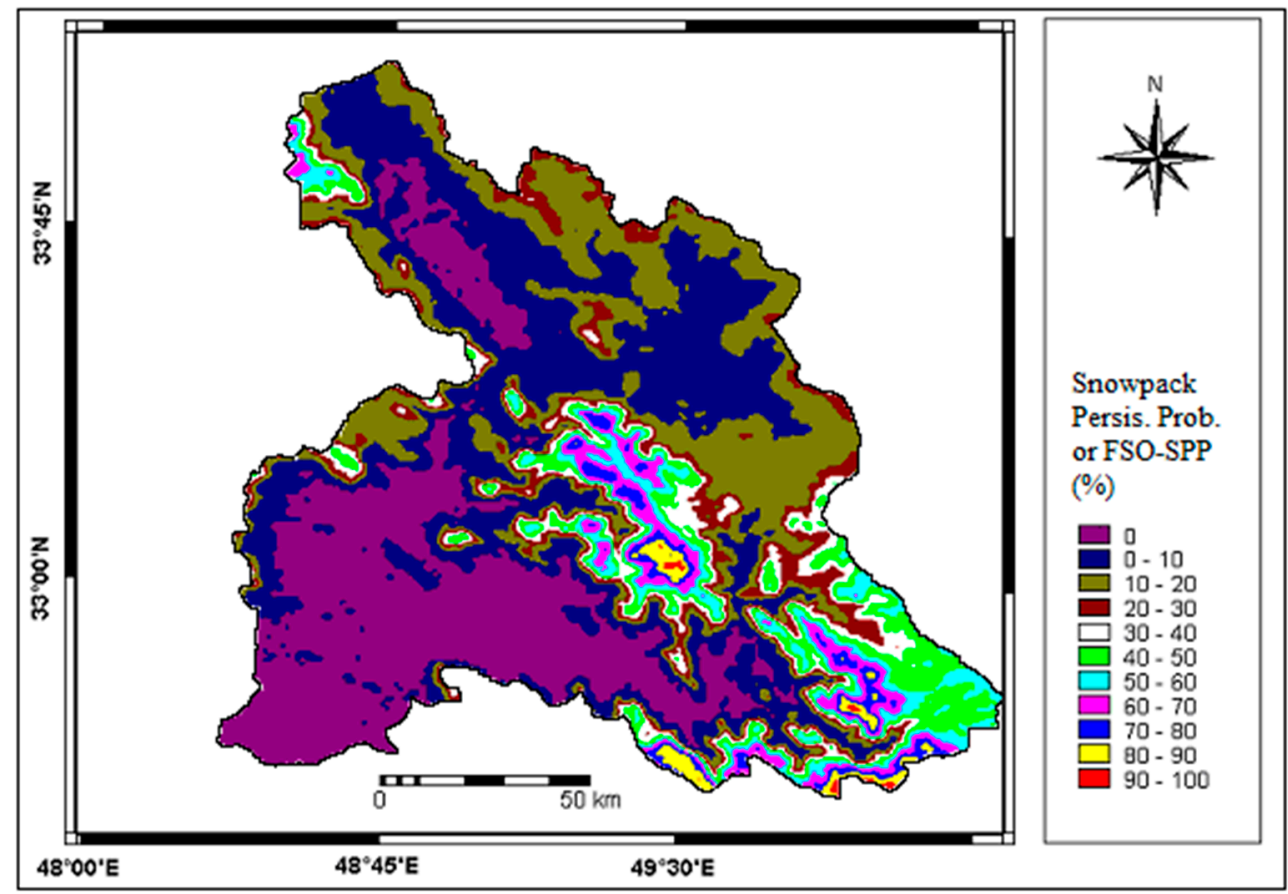

Figure 7. FSO-SPP Map in Dez Basin (for the period of 1984-2003).

\subsection{Site Selection and Station Type}

Site selection for snow stations is performed by integration of all available criteria including meteorological, hydrological and remotely-sensed variables. Site selection using the systematic and comprehensive approach described in this study will help decision makers to implement economically sound plans for optimizing a new set of stations or upgrading the existing network. This will be the case even where there is no historical snow data in the basin. In the study area, there is no historical snow data or MSC station available in Marun and Karkheh basins. Therefore, site selection of the snow stations is performed by integrating hydrological, meteorological and remotely-sensed variables. However, there are some operational MSC stations located in Karun and Dez Basins. Therefore, the refinement and optimizing of the existing network is performed based on the distribution of current stations and the error variance map, in addition to other variables mentioned above.

To make the proposed methodology more operationally practical, we choose to start the integration process from the altitudinal range of $250 \mathrm{~m}$ intervals and then generalize it to the basin scale. During the integrating phase, there is more emphasis on satellite images in terms of FSO-SFP and FSO-SPP criteria, due to the lack of homogeneous and long-term snow data. In the next step, meteorological and hydrological factors are also considered in order to compensate the impacts of snow data shortage. Since the site selection has been done in each individual elevation boundary, as an example, one of the altitudinal ranges of Dez Basin will be described in detail. This example shows step by step procedure that is followed in this research for all four major basins as follows.

The altitudinal range 2250-2500 m approximately covers $12 \%$ of the Dez Basin. The weighted average of FSO-SFP in this interval is about $40.8 \%$. There are 11 MSC stations in this interval as listed in Table 2. According to this table, the distribution of stations over elevation is relatively good. Dalooni and Barfian stations have the highest and lowest snowfall probability or FSO-SFP in this altitudinal range, with 57\% and 38\%, respectively. In addition, Dalooni and Yazdgerd stations have the highest and lowest snowpack persistence probability or FSO-SPP, with $38 \%$ and $25 \%$, respectively. Based on hydrologic criterion and road access, the ranking of each station is carried out for this altitudinal range. For example, in terms of road access, Ghaleh-Rostam and Yazdgerd stations are the most undesirable locations. 
Table 2. Existing manual snow-course (MSC) stations in altitudinal range of 2250-2500 m in Dez Basin.

\begin{tabular}{cccc}
\hline MSC Station & Elevation $(\mathbf{m})$ & FSO-SFP (\%) & FSO-SPP (\%) \\
\hline Vanaee & 2250 & 42 & 30 \\
Ghalavardeh2 & 2300 & 44 & 17 \\
Vazmeh-dar & 2300 & 48 & 32 \\
Ghaleh-rostam & 2300 & 32 & 10 \\
Aziz-abad & 2300 & 46 & 20 \\
Barfian & 2350 & 38 & 20 \\
Yazdgerd & 2500 & 44 & 25 \\
Palang-dar2 & 2400 & 46 & 26 \\
Dalooni & 2500 & 57 & 38 \\
Chahar-cheshmeh2 & 2400 & 46 & 18 \\
Gardanehe-khakbad & 2450 & 39 & 27 \\
\hline
\end{tabular}

To make a final decision, the weighted average snowfall probability in this altitudinal range (rounded to $40 \%$ ) is used as a criterion to determine the appropriate area for installing the stations. Thus, we set a threshold FSO-SFP of $40 \%$ to assess the present network. The selected zone for new stations is shown in Figure 8 along with the current station network. According to this figure, the existing network in this elevation has a desirable distribution, however, Ghaleh-rostam and Vazmeh-dar stations are close to each other and located at same elevation $(2300 \mathrm{~m})$. Therefore, one of the two stations should be removed. Vazmeh-dar station has more priority than Ghaleh-rostam station based on the FSO-SFP and FSO-SPP criteria, the ratio of winter precipitation to the annual precipitation, potential of snowfall, and road access. The two stations have similar contributions in snowmelt runoff according to the hydrological criteria. Therefore, Vazmeh-dar station is kept.

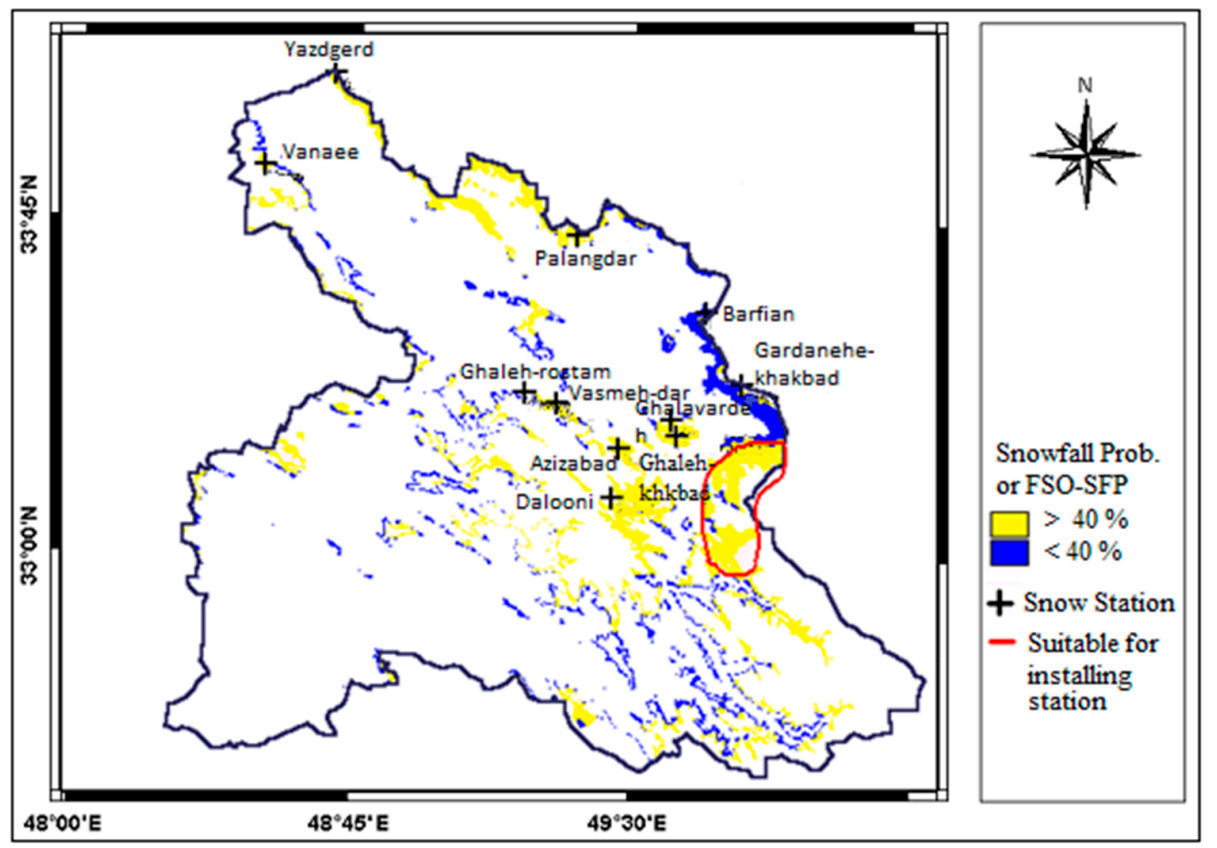

Figure 8. Selected zone for new snow stations and the existing station network in 2250-2500 m elevation interval in Dez Basin.

According to Figure 8 and the error variance map in Figure 4, spatial distribution of snow measurement stations in the 2250-2500 m elevation interval is generally appropriate while the error is relatively high in the west of the basin (shown by a thick polygon). Moreover, the average of snow persistence or FSO-SPP in this area exceeds 20\% (Figure 7). By checking on topography and road access, one location is proposed for a new station in the mentioned area. 


\section{Conclusions}

In this paper, a comprehensive approach for site selection of snow measurement stations in a mountainous area is proposed, based on an integration of meteorological, hydrological and remote sensing analysis. The approach is applied to a vast region encompassing four large river basins in the southwest of Iran. Snowfall and snowpack persistence probability maps are derived based on satellite images and used in a systematic site selection approach. Meteorological and hydrological variables such as basin average snowmelt and snowfall threshold temperature are included in the analysis to overcome lack of historical snow data availability.

The comprehensive site selection methodology for snow measurement stations not only ensures reliable snow data availability for the purpose of sustainable water resource management, but also provides an economically sound approach to optimize and maintain a cost-effective measurement network.

According to Moss [27], who emphasized economic considerations in network design, access (distance) to roads is considered as an indirect economic criterion for site selection of snow stations at local scale.

As a result of this study, six automatic snow-pillow stations (ASP) and four manual snow-course stations (MSC) in Karkheh basin; 17 ASP stations, 14 MSC stations and six control points in Dez Basin; 16 ASP stations, 10 MSC stations and 10 control points in Karun basin; and four ASP stations in Marun basin are proposed.

There is limited literature on design or evaluation of snow measurement networks in large spatial scale. The authors believe that the methodology described in this paper is a step forward for such studies, especially in data-poor regions where satellite information can play a significant role. However, there is room to improve on snow station network design in the future. One attractive alternative is to examine different scores for each input variable depending on their suitability, accuracy, and importance.

Acknowledgments: The authors acknowledge Jamab Consulting Engineering Co. for providing the snow cover map archive. Special thanks are also dedicated to the Khuzestan Water and Power Authority (KWPA) for partial support and providing companions in field trips.

Author Contributions: Bahram Saghafian and M. Reza Ghanbarpour proposed the original methodology for snow station site selection; Rahman Davtalab and Arezoo Rafieeinasab collected and analyzed the data and provided the results; Field trip were conducted by M. Reza Ghanbarpour and Rahman Davtalab; Bahram Saghafian, Arezoo Rafieeinasab, M. Reza Ghanbarpour and Rahman Davtalab jointly wrote the paper and addressed the comments.

Conflicts of Interest: The authors declare no conflict of interest. No one else was involved in the collection, analyses, or interpretation of data produced in this study; in the writing of the manuscript, nor in the decision to publish the results.

\section{References}

1. Iran Ministry of Energy (IRME). Karoun, Dez, Karkheh and Maroun River Basins Water Comprehensive Study—Second Study; Iran Ministry of Energy (IRME): Tehran, Iran, 2012.

2. Gyawali, R.; Watkins, D.W. Continuous hydrologic modeling of snow-affected watersheds in the Great Lakes Basin using HEC-HMS. J. Hydrol. Eng. 2013, 18, 29-39. [CrossRef]

3. Larson, L.W.; Peck, E.L. Accuracy of precipitation measurements for hydrologic modeling. Water Resour. Res. 1974, 10, 857-863. [CrossRef]

4. World Meteorological Organization (WMO). Snow Cover Measurements and Areal Assessment of Precipitation and Soil Moisture; Operational Hydrological Report No. 35; World Meteorological Organization (WMO): Geneva, Switzerland, 1992.

5. Quanta Consulting Engineering Co. Development and Modernization Plan of Iran Climatological Station; Iran Meteorological Organization Publication No. 1; Quanta: București, Romania, 1976.

6. Molotch, N.P.; Bales, R.C. Scaling snow observations from the point to the grid element: Implications for observation network design. Water Resour. Res. 2005, 41. [CrossRef] 
7. Brown, R.D.; Walker, A.E.; Goodison, B. Seasonal snow cover monitoring in Canada. In Proceedings of the 57th Eastern Snow Conference, Syracuse, NY, USA, 17-19 May 2000.

8. Bell, W.W.; Parmley, L.J.; Walk, H.; Afzal, H. Inflow forecasting for Pakistan's major reservoirs. Int. Water Power Dam Constr. 1994, 46, 21-26.

9. World Meteorological Organization (WMO). Guide to Hydrological Practices No. 168; World Meteorological Organization (WMO): Geneva, Switzerland, 1994.

10. Davtalab, R.; Madani, K.; Massah, A.; Farajzadeh, M. Evaluating the Effects of Climate Change on Water Reliability in Iran's Karkheh River Basin. In Proceedings of the World Environmental and Water Resources Congress 2014, Portland, OR, USA, 1-5 June 2014; pp. 2127-2135. [CrossRef]

11. Ashraf Vaghefi, S.; Mousavi, S.J.; Abbaspour, K.C.; Srinivasan, R.; Yang, H. Analyses of the impact of climate change on water resources components, drought and wheat yield in semiarid regions: Karkheh River Basin in Iran. Hydrol. Process 2014, 28, 2018-2032. [CrossRef]

12. Saghafian, B.; Davtalab, R. Mapping snow characteristics based on snow observation probability. Int. J. Climatol. 2007, 27, 1277-1286. [CrossRef]

13. Jamab Consulting Engineering Co. Karoun, Dez, Karkheh and Maroun River Basins Water Comprehensive Study_First Study; Jamab Consulting Engineering Co.: Tehran, Iran, 1991.

14. Porhemmat, J.; Saghafian, B.; Sedghi, H. An algorithm to mapping snow, cloud and land in NOAA AVHRR data, formulation, verification and evaluation. In Proceedings of the Fourth International Iran \& Russia Conference, Shahrekord, Iran, 8-10 September 2004.

15. Goovaerts, P. Geostatistics for Natural Resources Evaluation; Oxford University Press, Inc.: New York, NY, USA, 1997.

16. Saghafian, B.; Davtalab, R.; Kafayati, M. Comparison of methods for determining the snowfall threshold temperature and potential area affected by snowfall in the Karkheh, Dez, Karun and Marun river basins. Iran Water Resour. Res. 2016, 10, 31-39.

17. Fleming, M.; Neary, V. Continuous hydrologic modeling study with the hydrologic modeling system. J. Hydrol. Eng. 2004, 9, 175-183. [CrossRef]

18. Garcia, A.; Sainz, A.; Revilla, J.A.; Alvarez, C.; Juanes, J.A.; Puente, A. Surface water resources assessment in scarcely gauged basins in the north of Spain. J. Hydrol. 2008, 356, 312-326. [CrossRef]

19. Saghafian, B.; Bondarabadi, S. Validity of Regional Rainfall Spatial Distribution Methods in Mountainous Areas. J. Hydrol. Eng. 2008, 13, 531-540. [CrossRef]

20. Severino, E.; Alpuim, T. Spatiotemporal models in the estimation of area precipitation. Environmetrics 2005, 16, 773-802. [CrossRef]

21. Rango, A.; Martinec, J. Snow accumulation derived from modified depletion curves of snow coverage. In Proceedings of the Exeter Symposium on Hydrological Aspects of Alpine and High Mountain Areas, Exeter, UK, 19-30 July 1982; IAHS Publ. No. 138; IAHS Press: Wallingford, UK, 1982; pp. 83-90.

22. Ghanbarpour, M.R.; Saghafian, B.; Saravi, M.M.; Abbaspour, K. Evaluation of spatial and temporal variability of snow cover in a large mountainous basin in Iran. Nord. Hydrol. 2007, 38, 45-58. [CrossRef]

23. Simpson, J.J.; Stitt, J.R.; Sienko, M. Improved Estimates of the Areal Extent of Snow Cover from AVHRR Data. J. Hydrol. 1998, 204, 1-23. [CrossRef]

24. Martinec, J. The degree day factor for snowmelt runoff forecasting. In Proceedings of the IUGG General Assembly of Helsinki, IAHS Commission of Surface Waters, Helsinki, Finland, 25 July-6 August 1960; IAHS Publ. No. 51; IAHS Press: Wallingford, UK, 1960; pp. 468-477.

25. Akyurek, Z.; Sorman, A.U. Monitoring snow-covered areas using NOAA-AVHRR data in the eastern part of Turkey. Hydrol. Sci. J. 2002, 47, 243-252. [CrossRef]

26. World Meteorological Organization (WMO). The Planning of Meteorological Station Networks; Technical Note No. 111; World Meteorological Organization (WMO): Geneva, Switzerland, 1970.

27. Moss, M.E. Concepts and Techniques in Hydrological Network Design; Operational Hydrology Report No. 19; World Meteorological Organization: Geneva, Switzerland, 1982.

(C) 2016 by the authors; licensee MDPI, Basel, Switzerland. This article is an open access article distributed under the terms and conditions of the Creative Commons Attribution (CC-BY) license (http://creativecommons.org/licenses/by/4.0/). 